\title{
Entrepreneurial Orientation and Its Effect Toward SMEs Performance Through Strategic Flexibility on Fashion Industry in Malang
}

\author{
Pratasha Putra Kharisma ${ }^{1}$, Dodi W. Irawanto ${ }^{2}$, Ainur Rofiq ${ }^{3}$ \\ ${ }^{1}$ Correspondence Author: pratasha.putra@gmail.com \\ ${ }^{1,2,3}$ Magister of Management, Faculty of Economic and Business Brawijaya University, Indonesia
}

INDEXING

Keywords:

Innovativeness;

Risk-Taking;

Proactiveness;

Strategic Flexibility;

SME Performance;

Kata kunci:

Innovativeness;

Risk-Taking;

Proactiveness;

Strategic Flexibility;

SME Performance;

\begin{abstract}
The relationship between strategy and performance is central to the study of strategic management. The main objective of this study is to examine the form of entrepreneurial orientation towards strategic flexibility and SMEs performance. By taking a more specific sample, this study uses SMEs in fashion in Malang as the object of research. Data was collected through questionnaires, with 31 owners of SMEs fashion in Malang being taken as respondents. The findings of the study revealed that only proactiveness had a significant direct effect on SMEs performance, while innovativeness, risk taking and proactiveness significantly influenced strategic flexibility. Proactiveness was found to have the greatest influence on strategic flexibility. This study shows the important role of strategic flexibility in strengthening the effect of an entrepreneurial orientation on SMEs performance. Research implications and suggestions are discussed at the end of this article.
\end{abstract}

\begin{abstract}
ABSTRAK
Hubungan antara strategi dan kinerja adalah pusat studi manajemen strategis. Tujuan utama dari penelitian ini adalah untuk mengkaji bentuk orientasi kewirausahaan terhadap fleksibilitas strategis dan kinerja UKM. Dengan mengambil sampel yang lebih spesifik, penelitian ini menggunakan UKM fashion di Malang sebagai objek penelitian. Pengumpulan data dilakukan melalui kuesioner, dengan responden 31 pemilik UKM fashion di Malang. Temuan penelitian menunjukkan bahwa hanya proaktif yang berpengaruh langsung signifikan terhadap kinerja UKM, sedangkan inovasi, pengambilan risiko dan proaktif berpengaruh signifikan terhadap fleksibilitas strategis. Proaktif ditemukan memiliki pengaruh terbesar pada fleksibilitas strategis. Studi ini menunjukkan peran penting dari fleksibilitas strategis dalam memperkuat pengaruh orientasi kewirausahaan terhadap kinerja UKM. Implikasi dan saran penelitian dibahas di akhir artikel ini.
\end{abstract}

\section{INTRODUCTION}

Nowadays business climate and its environment have become increasingly complex and pose greater challenges for business practitioners. In such developing countries like Indonesia, around 95 percent of businesses are SMEs in which they usually represent a major source of innovation (Keizer et al., 2002), new job creation, and technological growth (Wiklund et al., 2009). While as a nation Indonesia is challenged to improve national competitiveness, SMEs have a strategic role can be considered as the backbone in supporting national's economic growth (Irjayanti and Azis, 2012). In fact, around 99 percent of SME business managers have a labor absorption rate of up to 97 percent and are continuously increasing in 2017 (Andriani et al., 2018). This is why SMEs have gained increasing attention and have contribute significantly to a nation's economy, especially in the areas of employment opportunities, poverty reduction, and income generation.

As a part of creative industry, the fashion industry is an important sector where firm strategies are more often product oriented towards personalization and customization more than product adjustments - at lower prices (Felice and Petrillo, 2013). Fashion 
industry sector is well recognized as a form of the creative industry category (Lin and Piercy, 2013) which contributes to improve economy. The industry is closely linked to the ability to provide customized products or services through flexible processes (Lewis and Hawksley, 1990) in high volume and relatively low cost, both of them are currently the key for supply chain mechanism in fashion industry. It will continues to improve its market position by reevaluating product and service and investing in new innovative marketing strategies in-store and online through multi-channel activities (Dholakia et al., 2005; Ashworth et al., 2006).

Strategic flexibility is closely related to environmental uncertainty (Nadkarni and Narayanan, 2007), when the external environment is in turbulence, SMEs need to develop greater flexibility which helps in guiding business through unpredictably changing environment. Fashion industry seems unstable or static, characterized by a changing environment where the industry continues to adjust products, services and images to meet consumer demand (Lewis and Hawksley, 1990). SMEs in fashion industry develops strategic plan as effort to improve its performance and competitive advantage (Felice and Petrillo, 2013). It also shows the significance of strategic flexibility as a dynamic capability that helps the firm to reallocate resources and break down existing operating routines (Zhou and $\mathrm{Wu}, 2010$ ). Cingoz and Akdogan (2013) explain that environment in which is constantly changing and full of uncertainty, a manager must have flexibility in building organizational strategic planning.

Focusing on small and medium-sized enterprises (SMEs) in area of fashion industry could be more beneficial and contribute to the national economy with as much as 2.8 percent of the total contribution of the creative industry sector. Fashion industry activities are run by as many as 90 percent of SMEs (Andriani et al., 2018). However the growth rate of SMEs in particular the fashion industry is classified as rebellious, and the failure rate of new SME fashion businesses is categorized high (Andriani et al., 2018).

While entrepreneurial orientation (EO) considered as one of the resource capabilities possessed in influencing SMEs performance, understanding the performance implications of EO in a SMEs context is becoming more important than ever as. Research has provided beneficial insight into the relationship between entrepreneurial orientation and SME performance. Previous theoretical and empirical studies have shown that dimensions of entrepreneurial orientation occured in different combinations (e.g. Covin et al., 2006; Lumpkin \& Dess, 2001). Each of them representing different aspects and independence of the multidimensional concept of entrepreneurial orientation (George and Marino, 2011). As a result, the dimension of entrepreneurial orientation allows it to have a different impact on the firm performance.

The study of contemporary entrepreneurship emphasizes the importance of efforts to enter business by innovating (Fairoz et al., 2010), where innovation is one of the important characteristics of an entrepreneurial orientation (Covin et al., 2006; Lumpkin \& Dess, 2001). Rauch et al. (2009) in their study emphasized the need to develop a valid and reliable scale of the dimensions of entrepreneurial orientation. George and Marino (2011) who was first identified in studying entrepreneurial orientation considered it not only in a single construct, but instead consisted of a collection of constructs of entrepreneurial orientation. It has been argued by Lumpkin and Dess (1996), which emphasize the construct, could vary with its dimensions in their level of significance and influence on performance. Regarding the three dimensions of entrepreneurial orientation, previous 
studies have explained the results of empirical findings could vary from each dimension on their outcomes (Lumpkin and Dess 1996; Lyon et al., 2000).

It is essential to upgrade the level of entrepreneurship and existing SMEs to be entrepreneurial orientated. Together with the current highly and borderless competitive and unvertainty environment, entrepreneurs are more often facing difficulty in operating their businesses. This will reflect their innovativeness, proactiveness and risk-taking qualities, which are particularly important for the growth and business performance of SMEs in the area. This study aims to examine the effect of innovativeness, risk taking, and proactiveness on strategic flexibility and SME performance in the fashion sector in Malang, East Java Indonesia.

\section{LITERATURE REVIEW AND CONCEPTUAL FRAMEWORK DEVELOPMENT}

Entrepreneurial strategic process, well known as entrepreneurial orientation or simply EO, is widely recognized as modes of strategy-making processes in the area of entrepreneurship. An comprehensive conceptualization of "entrepreneurial orientation" construct was provided by Lumpkin and Dess (1996). They have argued that entrepreneurial orientation refers to the practices, processes, and decision making activities that lead to new entry market or new product, additional to innovativeness, proactiveness, and risk taking, including tendencies to be aggressive toward competitors and to act autonomously. Entrepreneurial orientation could be systematically tested for the impact of each of its aspects relating to strategic decision making (Edmond and Wiklund, 2010), by identifying certain patterns of attitude or behavior that are believed to be important to emerge (Covin and Slevin, 1991; Lumpkin and Dess, 1996). In summary, the additional dynamic capabilities of the strategy flexibility among SMEs can be understood as the primary means of linking entrepreneurial orientation with the exploitation of business opportunities and achievable performance.

By separating the structure of the concept of entrepreneurial orientation, it is identified into three parts, namely innovativeness, risk taking behavior, and proactiveness. All of them can be linked to other things that allow different results. As Hughes and Morgan (2007) consider EO as a holistic higher-order construct consisting of dimensions that might behave differently from its parts. In existing literature, entrepreneurial orientation has been conceptualized with three to five dimensions, which may vary independently, according to Beattie (2016) and Richard et al. (2004).

Proactiveness and risk-taking is positively associated with business performance when the firm uses organic structures rather than mechanistic structures (Kreiser and Davis, 2010). Some of researchers argued entrepreneurial consist of five things : innovation, risk taking, proactivity, competitiveness aggressiveness, and autonomy (Cannavale and Nadali, 2018) and four things namely proactivity, ability to use resources, innovation, and risk taking (Hoque, 2018). It is commonly believed that the three constructs that widely accepted and have been commonly used in the literature of entrepreneurial orientation are innovativeness, risk-taking, and proactiveness. These three dimensions are believed to represent the form of entrepreneurial orientation that is recognized in micro, small and medium enterprise that embrace the type of organic structure, not mechanistic such as large established organizations. 
Based on previous scholars (Wiklund and Shepherd, 2005; Covin et al., 2006; Covin and Slevin, 1991; Lumpkin and Dess, 1996), three dimensions of entrepreneurial orientation explained below :

1. Innovativeness - a willingness to support creativity and experimentation in introducing new products or services, and technological leadership and R\&D in developing new processes.

2. Risk taking - the tendency to take bold actions such as venturing into an unknown new market, allocating resources for a business with uncertain results, and borrowing heavily on financial resources from external.

3. Proactive - opportunity seeking perspective, foresight that involves introducing new products or services in front of competitors and acting in anticipation of future demand to create change and shape the business environment.

Previous empirical findings highlighted the important link between entrepreneurial orientation and strategic flexibility (Kreiser and Davis, 2010; Nadkarni and Hermann, 2010; Arief et al., 2013). Flexibility allows efforts to emphasize the organization's rapid response to changes in external forces in an unpredictable environment, while mechanistic structures are applied better to a predictable environment where rapid response from the organization is not specifically required (Covin and Slevin, 1989).

Organizational flexibility is inherent in the organizational structure that drives the value of risk taking in organizations (Khandwalla, 1977). In this context, as SMEs need more innovative and valuable products for their markets, strategic flexibility is mostly adapted by SMEs in relates to uncertainty and outweigh the gains from standardized or consistent strategy. Strategic flexibility is defined as firm's capability to respond quickly in order to change competitive conditions (Herhausen \& Morgan, 2014). This capability is also about seek coherent structure, resources, and processes to support product innovation.

As uncertainty arise in external environment among business, there is a claim that risk taking in managing organization including opportunities and makes commitments to the use of resources before fully understanding what actions are needed to be taken. Thus, Covin and Wales (2018) argued certain qualities from one dimension of entrepreneurial orientation must exist that is innovation as the most important thing that reflects entrepreneurial orientation. Conceptual arguments have suggested that the EO dimension should be viewed as a separate but related construction, rather than as a unifying characteristic (Lumpkin \& Dess, 1996; Lyon et al., 2000). That is, firms can vary in their level of innovation, proactivity, and risk taking so they are not equally entrepreneurial in all dimensions. However, the suggested dimensions are positively correlated with each other (Lumpkin \& Dess, 1996), as it was empirically validated by Rauch et al., (2004).

Previous research also highlighting the important links between strategic flexibility and business performance (Nadkarni and Narayanan, 2007; Kapasuwan et al., 2007; Nadkarni and Hermann, 2010; Arief et al., 2013). Liyanage and Weerasinghe (2018) state that although strategic clarity is a crucial antecedent of business performance, there is very little attention to strategy flexibility for linkages with business performance. On the other hand flexibility is broad concept and used in various disciplines and different contexts (Kaur et al., 2017).

Existing literature depicts the relationship between entrepreneurial orientation and business performance (Kreiser et al., 2013; Wiklund and Shepherd, 2005; Rauch et al., 2004; Lumpkin and Dess, 2001). Accordingly, a business could get more positive benefits 
from entrepreneurial orientation (Herath and Mahmood, 2014). In some specific cases, proactivity and innovation are recognized as important things that could determine organizational performance or success (Kreiser and Davis, 2010). Empirical results show that entrepreneurial orientation is clearly related significantly business performance produced in a business or business (Mahmood and Hanafi, 2013; Kajalo and Lindblom, 2015; Cannavale and Nadali, 2018), and specifically on SME objects (Baker and Sinkula, 2009; Dharmanegara et al., 2018). Therefore, entrepreneurial orientation as a strategic capital owned by the business in an effort to achieve performance targets that have been set.

Business organizations proactively look for new business opportunities (Khandwalla, 1977). Furthermore, Miller and Friesen (1982) observed that entrepreneurial orientation tends to have a high emphasis on new product innovation. Such organizations are characterized by a willingness "to innovate boldly and in order while taking greater risks in product market strategies". A number of empirical studies in the past have shown a strong and positive relationship between the level of entrepreneurial orientation and the performance of SMEs (Lumpkin and Dess, 2001; Wiklund and Shepherd, 2005). Previously Covin and Slevin (1989) have emphasized that organic structure allows businesses to be flexible in capturing opportunities in the environment through proactive behavior of entrepreneurs (managers and or business owners who are in the business).

Entrepreneurial orientation and competitive advantage play an important role in improving the performance of the firm. Entrepreneurial orientation is a key success factor of the organization, as some studies indicates a positive relationship between entrepreneurial orientation and business performance (Zhang \& Zhang, 2012; Mahmood \& Hanafi, 2013; Mulyana and Sutapa, 2016). Entrepreneurial orientation arises from systematic testing of the entrepreneurial aspects of strategic decision making in companies that exist (Edmond \& Wiklund, 2010), and it becomes as a certain behavioral patterns that are believed to be important appear in a business (Covin and Slevin, 1991; Lumpkin and Dess, 1996).

However research on entrepreneurial orientation could be systematically tested for the impact of each of its aspects relating to strategic decision making (Edmond and Wiklund, 2010), with the identification of certain behavioral patterns that are believed to be important emerging (Covin and Slevin, 1991; Lumpkin and Dess, 1996). In summary, the additional dynamic capabilities of the strategy flexibility of SMEs could be understood as the primary means of linking entrepreneurial orientation with the exploitation of business opportunities and achievable performance. The research framework built in this study as depicted in Figure 1.

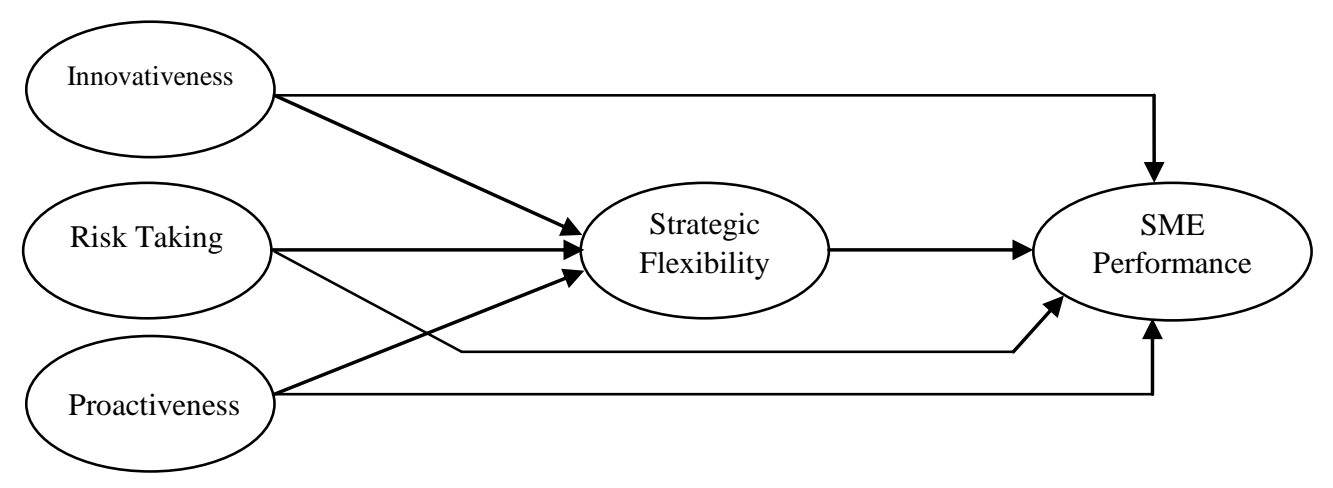


Figure 1. Conceptual Framework

Figure 1 show the conceptual framework of the research proposed in this study. There is a direct influence between innovativeness, risk taking, and proactiveness on SME performance and indirectly through strategic flexibility.

\section{RESEARCH METHOD}

Quantitative study methodology and closed questionnaire as the data-collection method used in this research. Based on quantitative research with a positivist approach towards EO, strategic flexibility and SMEs performance, empirical data were derived employing five standardized questionnaires about all of the observed variables measured in this study.

The data utilized in this study were collected from SMEs in Malang, East Java, Indonesia. The sampling method of the study is judgement sampling among nonprobability sampling methods. Sampling based on certain judgments involves selecting subjects who are in the most advantageous places or in the best position to provide the information needed (Sekaran and Bougie, 2013). Some considerations (Judgments) in the form of criteria used in determining the research sample are (1) having membership in associations or forums or fashion / distro industry associations in Malang City; (2) the business in fashion and or distribution has been running for at least two years. there are 31 Sactors in the fashion sector registered in the forum membership that have been formed since 2014, and are identified as meeting the criteria of the target sample specified above. The procedure for determining the sample is adjusted with careful consideration as stated by Sekaran and Bougie (2013).

For analyzing data, this study uses Structural Equation Modeling (SEM) though partial least squares (PLS), a structural equation modeling technique that uses a principalcomponent-based estimation approach (Chin, 1998). This study used 5-point interval scale with 1 representing to strongly disagree and 5 as strongly agree for all five constructs.

\section{RESULT AND DISCUSSION}

Table 1. Descriptive Statistic, Intercorrelation and PLS Quality Criteria

\begin{tabular}{|c|c|c|c|c|c|}
\hline & 1 & 2 & 3 & 4 & 5 \\
\hline 1. Innovativeness & $(.806)$ & & & & \\
\hline 2. $\quad$ Risk Taking & $0,809 * *$ & $(.871)$ & & & \\
\hline 3. $\quad$ Proactiveness & $0,593 * *$ & $0,839 * *$ & $(.784)$ & & \\
\hline 4. $\quad$ Strategic Flexibility & $0,740 * *$ & $0,824 * *$ & $.780 * *$ & $(.912)$ & \\
\hline 5. SME Performance & $0,699 * *$ & $0,856^{* *}$ & $.908 * *$ & $.868 * *$ & $(.874)$ \\
\hline Mean & 3.432 & 3.362 & 3.334 & 3.37 & 3.355 \\
\hline AVE & .567 & .658 & .537 & .698 & .619 \\
\hline Composite Reliability & .868 & .906 & .852 & .933 & .906 \\
\hline
\end{tabular}

Notes: **p, $0.01 ; * \mathrm{p}, 0.05$; Cronbach's alphas for each scale are italicized and shown in the diagonal. 
All correlations were found to be significant, with the result of intercorrelation of variables found to be positive between constructs. Reliability for both alpha cronbach and composite reliability were found to be above criteria threshold. Furthermore, all constructs observed in this study were categorized as reliable. In general this shows the consistency of data validity with previous studies.

This study found that innovativeness positively correlates with risk taking ( $r=0.809$, $p<0.001)$, proactiveness $(r=0.593, p<0.001)$, strategic flexibility $(r=0.740, p<0.001)$, and SME performance $(r=0.699, p<0.001)$. Risk taking positively correlates with proactiveness $(r=0.839, p<0.001)$, strategic flexibility $(r=0.824, p<0.001)$, and SME performance $(r=0.856, p<0.001)$. Proactiveness positively correlates with strategic flexibility $(r=0.780, p<0.001)$, and SME performance $(r=0.908, p<0.001)$. Finally, strategic flexibility positively correlates with SME performance $(r=0.868, p<0.001)$.

The loading value of majority over the criteria of 0.60 which illustrated the indicator of each construct able to measure own group with high loading values. Each construct has high composite reliability value indicated that good construct reflect role of such indicator.

Table 3.Goodness of Fit Evaluation

\begin{tabular}{|l|r|c|}
\hline Construct & R-square & Communality \\
\hline Innovativeness & & 0,5668 \\
\hline Risk-Taking & & 0,6577 \\
\hline Proactiveness & & 0,5372 \\
\hline Strategic Flexibility & 0,7362 & 0,6984 \\
\hline SME Performance & 0,8949 & 0,6191 \\
\hline Average & $\mathbf{0 , 8 1 5 5}$ & $\mathbf{0 , 6 1 5 8}$ \\
\hline
\end{tabular}

Table 3 shows the values of R-square and communality among observed variables in conceptual framework. Goodness of Fit in this study was assessed by the following equation: $\sqrt{ } \mathrm{AR} 2 *$ A.Com $=\sqrt{ } 0,8155 \times 0,6158=0,5022$. The value of 0.5022 indicates the model has a large predictive value. Q-Square Predictive Relevance also measured in this study with $Q^{2}=1-\left(1-\mathrm{R}_{1}{ }^{2}\right)\left(1-\mathrm{R}_{2}{ }^{2}\right)=1-(0,1051)(0,2639)=1-0,0277=0,9722$. In addition, 97.22 percent of Q-Square Predictive Relevance for the model of SME performance could be explained by innovativeness, risk taking, proactiveness and strategic flexibility.

To test the significance of the effect value on the relationship between variables, the structural equation model is estimated by involving five constructs, innovativeness, risk taking, proactiveness, strategic flexibility and SMEs performance.

Table 2. Path Coefficients of Relationship Between Variables

\begin{tabular}{|l|r|l|l|l|}
\hline \multicolumn{1}{|c|}{ Relationship } & $\begin{array}{r}\text { Path } \\
\text { Coefficient }\end{array}$ & t-Statistic & Cut-off & \multicolumn{1}{|c|}{ Remarks } \\
\hline Innovativeness -> Strategic Flexibility & 0,312 & 3,912 & 1,96 & Significant \\
\hline Risk Taking -> Strategic Flexibility & 0,241 & 2,023 & 1,96 & Significant \\
\hline Proactiveness -> Strategic Flexibility & 0,393 & 3,338 & 1,96 & Significant \\
\hline Innovativeness -> SME Performance & 0,095 & 1,773 & 1,96 & Not Significant \\
\hline Risk Taking -> SME Performance & 0,029 & 0,413 & 1,96 & Not Significant \\
\hline Proactiveness -> SME Performance & 0,573 & 7,088 & 1,96 & Significant \\
\hline Strategic Flexibility -> SME Performance & 0,326 & 4,945 & 1,96 & Significant \\
\hline
\end{tabular}


Based on table 2 it shows that among all of relationship in the research model, two of them were found to be insignificant, namely on the effect of innovativeness and risk taking on SME performance. The greatest coefficient value for significant influence is found on the effect of proactiveness on SME performance, while the value of the effect of risk taking on the flexibility of the strategy is found to be the lowest compared to other significant effect in the model.

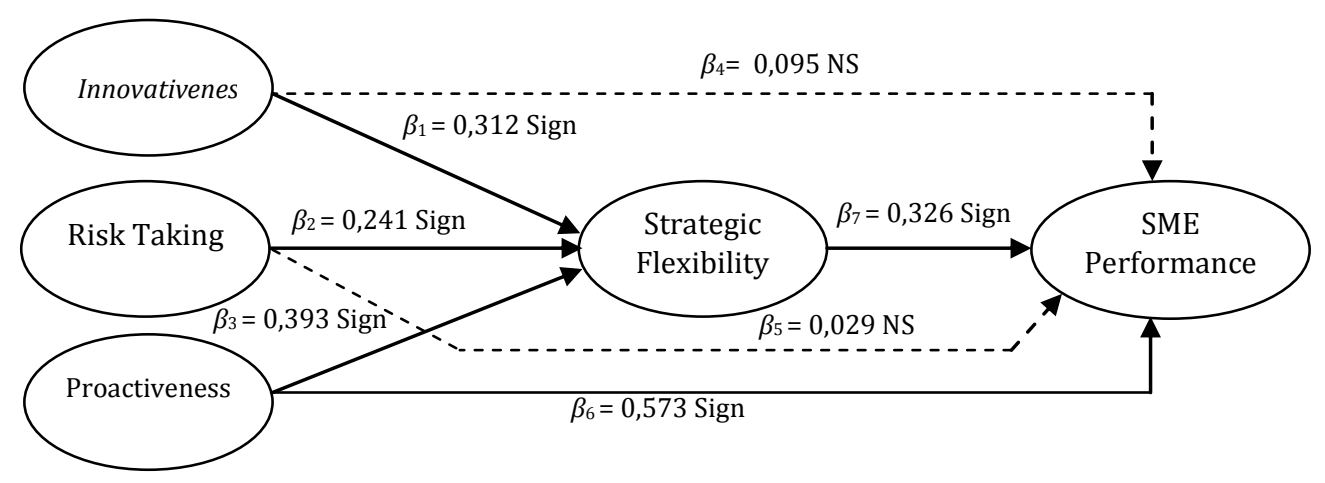

Figure 2. Path Coefficients between Variables

Figure 2 depicts the structural model assessed. From table 2 and figure 2 it can be seen the beta coefficient of the effect in the relationship between variables. Figure 2 revealed that the majority of variables had positive relations with innovativeness, risk taking, and proactiveness toward strategic flexibility with $\mathrm{R} 2$ value $=0.736$. Direct effect of innovativeness toward the strategic flexibility with the co-efficient path value equal to 0.312. Direct effect of risk taking toward the strategic flexibility with the co-efficient path value equal to 0.241 . Direct effect of proactiveness toward the strategic flexibility with the co-efficient path value equal to 0.393 . Only proactiveness (co-efficient path value equal to 0.573 ) and strategic flexibility (co-efficient path value equal to 0.326 ) found to have a significant effect on SMEs performance. Innovativeness $(\beta=0,095)$ and risk taking $(\beta=$ $0,029)$ were found to have no significant influence on improving SMEs performance of fashion sector in Malang. The $\mathrm{R}_{2}$ value of $\mathrm{SME}$ performance $=0.894$.

The findings of this study could not confirm some previous studies such as Zhang and Zhang (2012) which underline the significant meaningful relationships among innovativeness as part of entrepreneurial orientation on performance. While in the SMEs context, this result is not support previous empirical findings such as Mahmood and Hanafi (2013) and Hoque (2018) who explain the significant role of innovativeness on SMEs performance. As part of the derivative construct of entrepreneurial orientation, innovativeness has a reliable value among others but is found to have no significant effect to increase SMEs performance. The findings of this study are not in line with the findings of Mahmood and Hanafi (2013) and Hoque (2018). As part of the concept of entrepreneurial orientation which is revealed to be a stand-alone construct, risk taking has a reliable value but is found to have no important role in driving SME performance in fashion industry. 


\section{CONCLUSION}

This study contributes to a deeper understanding of the multidimensional framework of entrepreneurial orientation. Innovativeness, risk taking, proactivity are proven to be single construct could be examined separately. The results in the form of strategic flexibility and business performance at the MSMEs in Fashion in Malang. This study produces a final model framework based on the results of the analysis, by revealing the development of the conceptual model that has been tested, with emphasis on the finding that there are inconsistencies in the results of the direct influence of innovativeness and risk taking on SME performance. The findings also show that the framework of the research model built and tested in this study has the model with quite good criteria (validity and reliability).

The theory and empirical results of this study provide some interesting findings that contribute to several fields of scientific discussion. First, the research findings suggest that the relationship between entrepreneurial orientation and SME performance can be more complex than simple direct relationships. Second, the form of entrepreneurial orientation that is reviewed differently for each dimension may thus not be sufficient to directly influence organizational outcomes such as performance. It was revealed that only a proactiveness that is part of an entrepreneurial orientation can directly affect SME performance. In fact, in some cases SMEs must ensure that the existing entrepreneurial orientation develops into actual entrepreneurial behavior, especially to the extent that strategic flexibility that suitable in organizations to give better results. In this study, applying a weighted performance measure is undoubtedly useful for capturing the individual goals of a more flexible SME where exclusively financial performance indicators may not be suitable for general use given the different standardization of publicly listed companies as expressed by Wiklund and Shepherd (2005). However, the combined performance index covers a variety of effects of entrepreneurial activities on various measures of financial, non-financial, and growth-related performance.

This result provides information that can help managers and practitioners in SME context especially focusing on fashion industry design suitable initiatives for promoting strategic flexibility. It finds that the application of certain dimension of entrepreneurial orientation, such as proactiveness, can act as the first step towards building more dynamic capabilities in strategic flexibility to increase performance.

SMEs in fashion industry could focus on innovation and proactivity, and must consider alignment between the level of risk taking of an organization with the current resource basis and actual goals - whether securing actual performance through a low level of risk taking or opening new markets, which most likely to be successful when the small firm is oriented to a high level of risk. Risk taking is the most important thing to be addressed because in an environment is full of uncertainty. Business must be able to calculate and manage its risks properly, so that it can directly contribute to more positive results. Specifically, the approach to dealing with the contradictory effects of risk taking may be related to spatial separation from business development and daily business activities. To manage the implications of risk to individuals, SMEs in fashion industry could encourage risk taking in these functions related to business development, while at the same time continuing to suppress risk taking functions or parts related to daily business activities. 
This study is not without limitations. To begin with, a limited number of cases may be one of the possible reasons for no proven contribution of innovativeness and risk taking to SME performance, and may affect results due to poor representation. More empirical studies of heterogeneous cases can contribute to determining the role of strategic flexibility in SME performance based on entrepreneurial orientation construct. Another limitation is the subjective character of information provided and based of self-assesment.

Future studies are expected to be able to test the model on the characteristics of different or more diverse samples. So that differences can be compared between entrepreneurial orientations, strategic flexibility as predictors of business performance for different types of organizations or samples. In addition, further research is expected to examine and test other factors not found in this research model, especially relating to things that might play a role in determining the effect between entrepreneurial orientation and results such as business performance.

\section{References}

Andriani, M., Samadhi, T. M. A. A., Siswanto, J., \& Suryadi, K. (2018). Aligning business process maturity level with SMEs growth in Indonesian fashion industry. International Journal of Organizational Analysis, 00-00. doi:10.1108/ijoa-08-20171215.

Arief, M., Thoyib, A., Sudiro, A., Rohman,F. (2013).The Effect of Entrepreneurial Orientation on the Firm Performance through Strategic Flexibility: A Study on the SMEs Cluster in Malang. Journal of Management Research, 2013, Vol. 5, No. 3.

Ashworth, A., Schmidt, R., Pioch, E., Hallsworth, A. (2006).Web-weaving': an approach to sustainable e-retail and online advantage in lingerie fashion marketing.International Journal of Retail \& Distribution Management, Vol. 34 No. 6, pp. 497-511.

Beattie, S. (2016). Which Entrepreneurial Traits are the Most Critical in Determining Success? Otago Management Graduate Review, 14, 13-20.

Cannavale, C., Nadali,I.Z. (2018).Entrepreneurial Orientations and Performance: A Problematic Explanatory Approach in the Iranian Knowledge-Based Industry. The Journal of Entrepreneurship, 1-26. DOI: 10.1177/0971355718810295.

Cingoz, A., Akdogan, A.A. (2013).Strategic flexibility, environmental dynamism, and innovation performance: An empirical study. Procedia - Social and Behavioral Sciences, 99 (2013), $582-589$.

Covin, J.G., D.P. Slevin. (1989). Strategic Management of Small Firms in Hostile and Benign Environments. Strategic Management Journal 10: pp. 75-87.

Covin, J.G., D.P. Slevin. (1991).A Conceptual Model of Entrepreneurship as Firm Behavior.Entrepreneurship Theory and Practice 16 (1): pp. 7-25.

Covin, J.G., Green, K.M., \& Slevin, D.P. (2006). Strategic process effects on the entrepreneurial orientation-Sales growth rate relationships. Entrepreneurship Theory and Practice, 30(1), 57-81.

Dholakia, R.R., Zhao, M. and Dholakia, N. (2005).Multichannel retailing: a case study of early experiences. Journal of Interactive Marketing, Vol. 19 No. 2, pp. 63-74.

Edmond, V. P., \& Wiklund, J. (2010). The historic roots of entrepreneurial orientation research. In H. Lanström \& F. Lohrke (Eds.), The historical foundations of entrepreneurship research (pp. 142-160). Cheltenham, UK: Edward Elgar. 
Fairoz, F.M., Hirobumi,T., Tanaka, Y.(2010).Entrepreneurial Orientation and Business Performance of Small and Medium Scale Enterprises of Hambantota District Sri Lanka. Asian Social Science, Vol. 6, No.3.

Felice, F.D., Petrillo, A. (2013).Key Success Factors for Organizational Innovation in the Fashion Industry.International Journal of Engineering Business Management Special Issue on Innovations in Fashion Industry, Vol. 5, pp. 1 - 11.

George, B. A., \& Marino, L. (2011). The epistemology of entrepreneurial orientation: Conceptual formation, modeling, and operationalization. Entrepreneurship Theory and Practice, 35(5), 989-1024.

Ghozali, I. dan Latan, H. (2012). Partial Least Square: Konsep, Teknik dan Aplikasi. SmartPLS 2.0 M3. Badan Penerbit Universitas Diponegoro. Semarang.

Herhausen, D., \& Morgan, R. E. (2014). A Meta-Analysis of the Antecedents and Consequences of Strategic Flexibility. Academy of Management Best Papers Proceedings, 1-6.

Hoque, A.S.M.M. (2018). The effect of entrepreneurial orientation on Bangladeshi SME performance: Role of organizational culture. International Journal of Data and Network Science, (2018) 1-14.

Hughes, M., \& Morgan, R. E. (2007). Deconstructing the relationship between entrepreneurial orientation and business performance at the embryonic stage of firm growth. Industrial Marketing Management, 36(5), 651-661.

Irjayanti, M., Azis, A.M. (2012).Barrier Factors and Potential Solutions for Indonesian SMEs.Procedia Economics and Finance ,4 (2012) 3 - 12. doi: 10.1016/S22125671(12)00315-2.

Kajalo,S., Lindblom, A.(2015). Market orientation, entrepreneurial orientation and business performance among small retailers. International Journal of Retail \& Distribution Management, Vol. 43 Iss 7.

Kapasuwan, S., Rose, J., \& Tseng, C.-H. (2007). The Synergistic Effects of Strategic Flexibility and Technological Resources on Performance of SMEs. Journal of Small Business \& Entrepreneurship, $20 \quad$ (3), 257-272. doi:10.1080/08276331.2007.10593399.

Kaur, S. P., Kumar, J., \& Kumar, R. (2017). The Relationship Between Flexibility of Manufacturing System Components, Competitiveness of SMEs and Business Performance: A Study of Manufacturing SMEs in Northern India. Global Journal of Flexible Systems Management, 18(2), 123-137. doi:10.1007/s40171-016-0149-x.

Keizer, J. A., Dijkstra, L., \& Halman, J. I. (2002). Explaining innovative efforts of SMEs.: An exploratory survey among SMEs in the mechanical and electrical engineering sector in The Netherlands. Technovation, 22(1), 1-13.

Khandwalla, P.N. (1977).Some Top Management Styles, Their Context and Performance.Organization \& Administrative Sciences 7 (4): pp. 21-51.

Kreiser, P.M., Davis, J. (2010). Entrepreneurial Orientation and Firm Performance: The Unique Impact of Innovativeness, Proactiveness, and Risk-taking. Journal of Small Business and Entrepreneurship 23, no. 1 (2010): pp. 39-51. http://doi.org/10.1080/08276331.2010.10593472.

Lewis, B., Hawksley, A.(1990).Gaining competitive advantage in fashion retailing. International Journal of Retail \& Distribution Management, Vol. 18 No. 4, pp. 2132. 
Lin, S., Piercy, N. (2013). New Product Development Competencies and Capabilities : The Case of the fashion SME. Journal of General Management, Vol. 38 No.2 Winter 2012/2013, pp. $61-77$.

Liyanage A. S., Weerasinghe, T. D.(2018). The Effect of Strategic Flexibility on StrategyPerformance Nexus: A Conceptual Model. Kelaniya Journal of Management, Vol. 07, Issue 01, pp. 26 - 39. DOI: http://10.4038/kjm.v7i1.7552.

Lumpkin, G. T., \& Dess, G. G. (1996). Clarifying the entrepreneurial orientation construct and linking it to performance. Academy of Management Journal,21(1), 135-172.

Lumpkin, G. T., \& Dess, G. G. (2001). Linking two dimensions of entrepreneurial orientation to firm performance: The moderating role of environment and industry life cycle. Journal of Business Venturing, 16, 429-451.

Lyon,D.W.,Lumpkin,G.T.\&Dess,G.G.(2000).Enhancing entrepreneurial orientation research: Operationalizing and measuring a key strategic decision making process. Journal of Management, 26(5), 1055-1085.

Mahmood, R., Hanafi, N. (2013). Entrepreneurial Orientation and Business Performance of Women-Owned Small and Medium Enterprises in Malaysia: Competitive Advantage as a Mediator. International Journal of Business and Social Science Vol. 4 No. 1; January 2013.

Miller, D. \& Friesen, P.H. (1982). Innovation in conservative and entrepreneurial firms: Two models of strategic momentum. Strategic Management Journal, 3 : 1-25.

Mulyana \& Sutapa.(2016). The Impact of Entrepreneurial Orientation and Collaborative Networks on Creative Industries Performance.Jurnal Dinamika Manajemen, 7 (2) 2016, 166-181.

Nadkarni, S., Narayanan, V.K. (2007). Strategic schemas, strategic flexibility, and firm performance: the moderating role of industry clockspeed. Strategic Management Journal, Vol. 28, pp. 243-70.

Nadkarni, S., \& Herrmann, P. (2010). CEO Personality, Strategic Flexibility, and Firm Performance: The Case of the Indian Business Process Outsourcing Industry. Academy of Management Journal, 53(5), 1050-1073. doi:10.5465/amj.2010.54533196.

Rauch, A., Wiklund, J., Freese, M., \& Lumpkin, G. T. (2004). Entrepreneurial orientation and business performance: Cumulative empirical evidence. Paper presented at the 23rd Babson College Entrepreneurship Research Conference. Glasgow, UK.

Rauch, A., Wiklund, J., Lumpkin, G. T., \& Frese, M. (2009). Entrepreneurial orientation and business performance: An assessment of past research and suggestions for the future. Entrepreneurship Theory and Practice,33(3), 761-787.

Richard, O. C., Barnett, T., Dwyer, S., \& Chadwick, K. (2004). Cultural diversity in management, firm performance, and the moderating role of entrepreneurial orientation dimensions. Academy of Management Journal, 47(2), 255-266.

Sekaran, U., Bougie, R. (2013). Research Methods for Business A Skill-Building Approach. Sixth Edition. Wiley. New York.

Wiklund, J., Shepherd, D.(2005).Entrepreneurial Orientation and Small Business Performance: A Configurational Approach. Journal of Business Venturing 20 (1): pp. 71-91.

Wiklund, J., Patzelt, H., \& Shepherd, D. A. (2009). Building an integrative model of small business growth. Small Business Economics,32(4), 351-374. 
Zhang, Y., Zhang, X. (2012). The effect of entrepreneurial orientation on business performance. A role of network capabilities in China. Journal of Chinese Entrepreneurship. 4 (2): 132- 142.

Zhou, K. Z., \& Wu, F. (2010). Technological capability, strategic flexibility, and product innovation. Strategic Management Journal, 31, 547 - 561. DOI:10.1002/smj.830. 